\title{
ELECTRONIC COMMERCE IN THE INTERNATIONAL TRADE AND THE IMPACT ON INDONESIA
}

\author{
Wenny Setiawati ${ }^{1}$
}

\begin{abstract}
Abstrak
This paper observes the development in the discussion of e-commerce as a cross cutting issue in WTO and how the issue affected Indonesia primarily in the information and communication technology (ICT) area. The exploration will focus on e-commerce discussion and the progress starting from the First Ministerial Conference to the Fifth. The observation will also broaden to all related issue of the topic in this research, such as intellectual property rights and ICT. Under the author analysis, there is one thing that Indonesian government can take advantage, the joining in Information Technology Agreement (ITA). Because ITA was, establish in the purpose of encouraging nations to develop their ICT so there will be development in the ICT in order to create of fair competition. The encouragements were given in the form of reducing custom and duties on technology used for ICT. More author opinion that Indonesia must see ITA as the facility in building up the ICT in the country, despite the debate on the categorization of e-commerce, whether as good or service. Indonesia must take an immediate step redeem necessary to compete in the globalization of commerce, and maximizing the ICT development through available facility is one possible step right now.
\end{abstract}

Kata kunci: hukum bisnis, perdagangan internasional, transaksi elektronik, dampak

\section{Introduction}

\section{A. Background}

One of the issues still in debate among WTO's member countries is electronic commerce (e-commerce). From the establishment of WTO until the Fifth Ministerial Conference in Cancun, in 2003, the debate on the issue has not accomplished a great deal improvement as

${ }^{1}$ Writer is a Lecturer in Law Faculty, Universitas Indonesia. This paper is written for the purpose of a research conducted by the writer in the program constructed by European Union-Indonesia Trade Support Program with the Ministry of Trade Republic of Indonesia. 
other issues in the agenda. The first consensus reached in 1998 in the Second Ministerial Conference in Geneva, where the issue of ecommerce swiftly outpaced the practice of it. In this Second Ministerial Conference on 20 May 1998, the members were to adopt declaration on global electronic commerce which directed the WTO General Council to establish a comprehensive work programme to examine all trade related issues arising from e-commerce, and to present a progress report to WTO's Third Ministerial Conference. ${ }^{2}$

A moratorium is included in the 1998 declaration stating that the current practice of not imposing custom duties on the electronic transmission will be continued. Meanwhile many reports from member countries have prolonged the debate upon this issue, with many insights from different angles that show interesting problem matters which caused the consensus seems more distant.

The work programme was adopted by the WTO on 25 September 1998 to be continued by Third Ministerial Conference in Seattle, in November 1999. The Fourth Ministerial Conference in Doha in 2001 resulted on the extension of the moratorium. And in the Fifth Ministerial Conference in Cancun in 2003, this issue remain a cross cutting issue that held a heated debate between countries in favor to moratorium and which are not.

What makes this issue a cross cutting issue? Perceptibly, because e-commerce has a potential relevance that may cut across in many different agreements of the multilateral system. ${ }^{3}$ This issue is for sure related to TRIPS, GATS and GATT, although whether e-commerce should falls under GATS or GATT is still debatable. There are so many problems arising from the discussion on the question to regulate e-commerce in the WTO. Those problems are the classification of electronic transmission, development related issue, fiscal implications of e-commerce, relation between e-commerce and traditional form of commerce, imposition of customs duties on electronic transmission, competition, and jurisdiction and applicable law.

It is interesting to delve into the issue in debate and still in the process of resulting the best way for every member to abide. Especially when the issue at hand is become quite a substantial

2 "Electronic Commerce: Briefing Note. Work Continues on Issues Needing Clarification”, <http://www.wto.org/english /tratop_e/ecom_e/ecom_briefnote_e.htm>, accessed 2 February 2008.

${ }^{3} I d$. 
problem for developed and developing countries. E-commerce become a problem for developed and developing countries because the information and communication technology (ICT), the basis of ecommerce, has seeped into the culture of its society, change the behavior of doing things, improving standard of life, enhancing wealth of the people, and leads to advance development in all areas. That is why countries fighting upon the issue, because any decision will affect domestic stability and therefore each country took a stand to secure it.

Whereas for Indonesia, technology is still the monopoly of certain level of society, the middle to upper economic level, because it costly for most Indonesian which still falls under the low economic level or in poverty. This middle to upper economic level of society is of course located in provinces or big cities whereas the coverage is available while in the rural areas, which construct most of Indonesia area, are still yearning for electricity. The technology gap between big cities and rural areas is troublesome for the ICT development, because how a country could enhance the ICT usage if even the minor aspect in supporting the ICT, such as electricity, is scarce. Even the monopoly of state owned telephone company has not made vast development in providing ICT to all area of Indonesia; only after some strict regulation being lifted which allowed foreign investment that some development is seen. Still, the development is minor compared to development in developing countries, and minuscule to developed countries.

Albeit the poor dispersal of technology, Indonesia is undoubtedly a player in the world of ICT. The certain level of society which enjoys the ICT development is the key for this, because they usually up dated to new development which affecting the consumption on ICT. Also, the R\&D in this area is occurring continuously either by personal or institution. The fact of Indonesia as a player in the international ICT world is becomes the answer why Indonesia needs to take part in the discussion of e-commerce in WTO or at least pay much attention to it. With many possibilities ahead, it is necessary to take precaution steps in order to secure the development of ICT in Indonesia, and by taking part in the process of solving the cross cutting issue of e-commerce that Indonesia can figure out the steps to take. 


\section{B. Objectives}

This paper is intended:

1) To give insights on the issue of e-commerce in the WTO and what accomplishment has resulted from the pathways of discussion and agreements among members?

2) With the development in the discussion, then the problems related to Indonesia can be distillated?

3) To find out where Indonesia's stand on the matter and how the issue affected Indonesia's ICT and development?

\section{Hypothesis}

This paper will observe the development in the discussion of ecommerce as a cross cutting issue in WTO and how the issue affected Indonesia primarily in the ICT area. Observation will focus on ecommerce discussion and the progress starting from the First Ministerial Conference to the Fifth. The observation will also broaden to all related issue of the topic in this research, such as intellectual property rights and ICT.

The research will be based on literature research whether in the digital form or books and papers. The literature will not be limited only to WTO papers and reports but also from country reports that supporting the discussion in WTO. Personal paper will also be noted to give different viewpoint or to add information related to the issue.

The collected information will be used to analyze the Indonesia's standpoint in the presented issue. Analysis will be done within the framework of international trade and the legal aspect of it.

\section{E-Commerce In WTO}

Before the establishment of WTO, e-commerce has become the worldwide discourse. The invention of the Internet on the late $20^{\text {th }}$ century, which became the mean for e-commerce, has given a new meaning to information and communication. With the Internet, information is transferred in a matter of seconds and of course this is one way of efficiency. Not to mention this technology has a cross boundary system which enables a wider connection among people in the world. Despite the first use of this technology was to support defense mechanism, the development of Internet 
has widened the application which currently take place in almost all aspects of life.

This technology also tinted the development in commerce which emerged into a new era by the usage of various information and communication technology in doing commerce. The idea of using technology in doing commerce is to achieve a higher profit because it reduces the cost and the time length in the transaction process. With the technology, commerce runs more efficiently thus a wider possibility has opened for seller to reach more buyers, because it allowed the interaction between parties across the border of nations.

This is where the problems starting to rise, because of the way of Internet has enable parties to do transaction without have any physical contact. Just like two sides of a coin, the benefit of e-commerce comes along with the detriment. Threats to e-commerce come in many forms; fraud is come easily such as the assurance that the transaction partner, either the seller or the buyer, is the rightful one that will ensure the fulfillment of transaction. Another threat is related to data protection, because when a transaction is made, there are three stages in it, first stage is the pre purchase stage which included advertising and information seeking, followed by the stage of purchase and finally is the delivery stage ${ }^{4}$, In all of those stages data either from the seller or the buyer is necessary, in order to ensure the validity of the transaction, this data include identification of parties, bank account, or credit card number. If the parties survived from these threats, still does not mean they are safe, since threat may come from outsider like hacker or cracker. Not to mention aside from those threat there are still problems arising from abusive behavior in the Internet that also need attention from the government.

All of the troubles came from e-commerce has made developed country like United States put their best effort in securing the practice and the society from all threats and problems, and still the development of the technology and the widespread usage of it has made the task more difficult each time. This task is even more difficult when it comes to trans national problems that needs to be settled by countries agreement. With different points of view, culture, level of technology, the society literacy on technology, economic, and policy, country needs to find solution and reach consensus with other country without have to lessen the level of protection intended for domestic.

${ }^{4}$ Ludger Schuknecht, "A Quantitative Assessment of Electronic Commerce, September 1999. Staff Working Paper ERAD-99-01", <http://www.wto.org/english/ res_e/reser_e/ae9901_e.htm>, acessed 8 February 2008. 
This is where WTO plays important role as the means for countries to reach consensus that will protect not only one country but also all country in the world. Member countries get together to find the best way to settle the problems in e-commerce. Despite all domestic interests, countries met and discussed on how make a better environment for e-commerce with protection of the future as the purpose.

\section{A. First Ministerial Declaration to The Fifth}

To find out the stand of Indonesia in the issue of e-commerce in WTO, first step is to observe the progress of the discussion from the First Ministerial Declaration to the Fifth. This is necessary to obtain important information on the discussion which is the background on the decision; the background information will tell us what interests lie behind the decision. Therefore, adjusting to the decision on the matter then Indonesia will know which right step to take.

The First Ministerial Conference took place in Singapore in 1996. The issue of e-commerce was not in the agenda of this conference yet, because the major concern is placed upon tariff, non tariff policy, services, intellectual property, dispute settlement, textile, agriculture, and shaping the WTO. ${ }^{5}$ The absence does not mean the issue of ecommerce was left behind, in fact after this First Ministerial Meeting; there was continuing discussion on what problems should be brought into the WTO meeting, and e-commerce was one of it. At the moment, the first thing that had all member states agreement were the Basic Telecommunication Agreement (BTA) and Information Technology Agreement (ITA) which regulates tariff cutting mechanism for infrastructure for information technology. ${ }^{6}$ Those two agreements were easier to settle than the issue of e-commerce. Still, member countries debated on how the ITA only focusing on the infrastructure instead on the trade issue which is vaguer and need immediate clarification.

That was why when the Second Ministerial Conference carried out in 1998 in Geneva, e-commerce was one of the cross cutting issues. Because almost all WTO disciplines were affected by e-

5 Sekilas WTO, Direktorat Perdagangan, Perindustrian, Investasi dan HKI, Departemen Luar Negeri, (Directorate of Trade, Industry, Investment and Intellectual Property. Foreign Ministry).

6 "Information Technology: Introduction. Information Technology AgreementIntroduction", <http://www.wto.org/english/tratop_e/inftec_e/itaintro_e.htm>, acessed 8 February 2008. 
commerce: services, intellectual property, goods, government procurement, TRIPS and technical barrier to trade. ${ }^{7}$ The Second Ministerial Conference resulted in declaration on global electronic commerce for members to adopt. The declaration directed the WTO General Council to establish a comprehensive work programme to examine all trade related issues arising from e-commerce, and to present a progress report to WTO's Third Ministerial Conference. ${ }^{8}$

A moratorium is included in the 1998 declaration stating that the current practice of not imposing custom duties on the electronic transmission will be continued. Meanwhile many reports from member countries have prolonged the debate upon this issue, with many insights from different angles that show interesting problem matters which caused the consensus seems more distant. At least in this Second Ministerial Meeting, members had agreed on two things, first thing is the type of e-commerce in the cross cutting issue, which is not e-commerce in broad definition but only production, distribution, marketing, sale or delivery of goods and services by electronic means. ${ }^{9}$ That was why the term used in the declaration is "electronic transmission".

Debate on the issue was continued after the Second Ministerial Meeting ended. Pros and cons kept fighting; arguments were launch to counter others. Then the Third Ministerial Conference took place in Seattle in 1999. Followed by the Fourth Ministerial Conference was in Doha, Qatar in 2001; the Fifth in Cancun, Mexico in 2003 and the last one, The Sixth, was in 2005 in Hong Kong. ${ }^{10}$ In all of these Ministerial Conferences, e-commerce still became an issue that draws many eyes on it. In each conference, the result on e-commerce issue was still the same which was to maintain the current practice of not imposing customs duties on electronic transmission. In the last three conferences, e-commerce was not the main focus, since Doha main

${ }^{7}$ Work Programme on Electronic Commerce, "Submission by the United States. 12 February 1999. WT/GC/16", <http://www.wto.org/english/tratop_e/ecom_e/16_e.doc>, acessed 8 February 2008.

8 Electronic Commerce, "Briefing Note. Work Continues on Issues Needing Clarification", <http://www.wto.org/english /tratop_e/ecom_e/ecom_briefnote_e.htm>, acessed 8 February 2008.

${ }^{9}$ Id.

${ }^{10}$ Sekilas WTO, supra. 
agenda was on agriculture; trade on services, industrial tariff, environment issue, intellectual property rights, dispute settlement and WTO rules. ${ }^{11}$

In the Sixth Ministerial Conference in Hong Kong, there was an additional concern on the issue, electronically delivered software. This concern was based on how e-commerce has the ability to transform goods transmitted electronically, for example books, music, movies and now software. But those examples were digitized from the former physical existence of products while software is something that can be classified as intangible and because of technology development, this intangible product can be transmitted worldwide and made the identification harder than before. That was why the number of member states which support the discussion on the issue became bigger, with same purpose, to clarify the classification of electronic transmission.

The urge is understandable, with the growing practice of ecommerce in the world and in addition to that is the unknown development of technology which outpaced even the domestic policy, and here countries intend to format a common policy among them to regulate something that still in haze for most countries.

\section{B. The Debate on the Issue}

To understand what has become the center of those debates then it is necessary to go through each topic of the debates one by one. In this section are the extract of the debates on e-commerce and these debates coming from many countries and not limited by countries' private war. Private war, figuratively speaking, is between US and EC, because from these two countries are the most argumentative compared to others. US' opinion based on the idea of maintaining the current liberal trade environment in e-commerce while EC's opinion based onto the idea of the GATS and GATT are applicable on e-commerce and to regulatory autonomy in this matter. ${ }^{12}$ This issue will be discussed further in the next section.

"Id.

${ }^{12}$ Sacha Wunsch-V incent, "Outstanding WTO Issues and Deliverables with Respect to the Electronic Cross-border Trade of Digital Products. Thesis: Draft of Chapter 2, The WTO and the Liberalization of Cross-border Electronic Services: a translantic perspective. Washington DC, October 19, 2002", <http//www.cid.harvard.edu/cidtrade/Papers/ Wunsch_WTO.pdf $>$, acessed 8 February 2008. 
1. Classification of electronic transmission, whether it should be classified as goods (GATT) or as services (GATS)

One discourse most debated in the sequences of the Ministerial Conferences was concerning the classification of electronic transmission. US and EC were on the different sides about this, both countries had their arguments on their opinion and they kept in the opposition with each other while other member states gave their favor either to US or to EC, but there were in the abstain position or observed the development was more precise.

The US preferred electronic transmission to be categorized as goods which means will be regulated under the GATT provisions whilst the EC preferred GATS apply to this issue. First there is problem about the basic definition of "goods" and "services" in both agreements which there are none, then how the categorization should be made?

Software on carrier media covered under ITA which the industrialized country signatories have agreed to a zero tariff line by the year $2000 .^{13}$ It means the countries had agreed upon the existence of software as goods. The US then argued that no matter what is the carrier of the software, even if the software were transmitted over the Internet then it should still be categorized as goods. ${ }^{14}$ This categorization also applies to audiovisual transmission, such as book, movies, music delivered over the Internet.

The EC pointed out that when products delivered physically then GATT applied, instead if products delivered through electronic transmission then it considered as services which GATS applied. ${ }^{15}$ The same principle goes to software, when software placed in a media which has physical form then it can be considered as goods, but if the software is delivered over the Internet then the transmissions is considered as services. ${ }^{16}$ The EC

$13 \mathrm{Id}$

${ }^{14} \mathrm{Id}$.

15 Preparations for the 1999 Ministerial Conference. Compilation of Proposals Submitted in Phase 2 of the Preparatory Process. JOB(99)/4797/Rev.3.

${ }^{16} \mathrm{Id}$. 
also argued that there is no need to be confuse on the applicability of GATS and GATT upon electronic transmission, since if the products were delivered in physical form then the GATT applies, but if the products are transmitted electronically then GATS applies.

The US countered this argument that if to the same products to be treated differently according to the delivery means then there will be a confusion if the product at issue is software transmitted electronically. A given example of this issue can be described like this, an entertainment games may change their physical carrier medium during transaction. A game manufacturer may copy content of game $\mathrm{CD}$ onto a hard drive, send it to the consumer over the Internet who then burns the game on a $\mathrm{CD}$. In nearly all such situations the content is intricately linked to a physical object and digital products are not consumed during consumption. Both this "durability" and the inseparability from a physical medium mean that digital products are rather a good than a service. ${ }^{17}$ The US also states that since the establishment of GATT, the EC has insisted that electricity should be considered as a good and not a service whilst the comparison between electricity and digital products in term of comparability almost the same. ${ }^{18}$ Confusion is also rise in the matter of distinguishing goods or services on the output of professional services such as engineering designs that traditionally had a physical equivalent with a Harmonized System tariff line, but it can be delivered online. ${ }^{19}$

The EC answers this challenge with stating that GATS still applicable to those issues. There are four modes available in the GATS provisions for sample cases presented before ${ }^{20}$, and they stand on their argument based on services should not treated differently because it was delivered through another type of technology. ${ }^{21}$

${ }^{17}$ Id.

${ }^{18} I d$.

${ }^{19}$ Id.

${ }^{20}$ Preparations for the 1999 Ministerial Conference. Compilation of Proposals Submitted in Phase 2 of the Preparatory Process. JOB(99)/4797/Rev.3.

${ }^{21} I d$. 
Another argument why the US placed their preference on GATT was that GATT is friendlier than GATS whereas every rule applied in certainty, while in GATS provisions were not developed yet. Therefore, the uncertainty in GATS may endanger the liberalization in e-commerce. ${ }^{22}$ As mentioned before that for software on carrier media covered under ITA and the industrialized country signatories have agreed to a zero tariff line by the year 2000. If GATS applied to electronic transmission then countries may exercise measures on digitized products, and that will adding cost to the production. Because GATS enable countries to have a discriminatory tax regulations or customs duties as long as they not made national treatment commitments. ${ }^{23}$

US argue GATT protects member countries with same treatment, and countries must obey the same regulation which is internationally applied. Fairness is what lacks from GATS provision, because countries might be able to place measure or barrier if they not made any commitment to open their market access. And this is because GATS has no agreement on antidumping, on safeguard measures, on trade related investments or on rules of origin. ${ }^{24}$ Confusion in regard of classification has already became the source of heated and long discussion, not to mention the application in the future dispute settlement that will raise more question mark, which treaty to apply regarding to electronic transmission for digitized products case.

According to EC, internet access and network services are telecommunication services. Therefore the obligations of the GATS Telecoms Annex on 'access to and use of' public telecommunications networks and services apply to internet access and internet network services. Sources stated that EC delivered different opinion on the matter for the purpose of protecting the regulatory autonomy, especially when US is the major supplier for products transmitted electronically, therefore EC argued to protect the worldwide industry from anti competitive practices the autonomy in deciding which services can access should apply to electronic transmission.

\footnotetext{
${ }^{22}$ Sacha Wunsch-Vincent. Supra.

${ }^{23} \mathrm{Id}$.

${ }^{24}$ Id
} 
Until now, the debate is still went on with countries favor to US like Japan and Canada, while EC is supported by its member countries.

\section{Whether the moratorium from the 1998 Ministerial Conference should be made permanent}

Another big question is whether the moratorium 1998 should apply permanently. The EC argued that moratorium only applies to trade transactions that are entirely electronic which means if a good is ordered electronically, but physically delivered, then this general duty-free status does not come into play, but the existing GATT commitments (for example ordering books from Amazon). ${ }^{25}$ Therefore, there is no need to make the moratorium permanent.

As usual the US suggested the opposite, according to studies on e-commerce resulted that only a very small percentage of tradable products can be digitized which make the income from custom duties that may derived from electronically transmitted goods is thus very small in volume, namely less than one percent of the worldwide income from customs duties. ${ }^{26}$ Since the income from customs and duties is insignificant to domestic growth income, the US recommended for moratorium to be permanent. Another reason is if customs and duties to be levied then customs authorities would need to be able to trace and establish the value of commercial electronic transaction. ${ }^{27}$ Even if this is possible, it is highly doubtful whether the levies would outweigh the costs of this process. ${ }^{28}$

But member countries should consider the possibilities that may came out in the future development of technology. Whatever decision to be made in the next meeting, countries will have to remember that society dependence on information technology will increase along with technology development which will support it.

\footnotetext{
${ }^{25}$ Sacha Wunsch-Vincent. Supra.

${ }^{26} \mathrm{Id}$.

${ }^{27}$ Id.

${ }^{28} \mathrm{Id}$
} 


\section{Analysis}

\section{A. Indonesia Position in Discussion}

According to the 1999 Indonesia Statement, it seems Indonesia has not gripped the focus of the debate upon the issue of electronic transmission. Although Indonesia agree on the effort to reduce the cost of goods and services transmitted electronically, but there was inquiry on the impact of e-commerce to the economic, financial and development needs. ${ }^{29}$ Nevertheless, Indonesia agreed upon the extension on the moratorium without given any argument. ${ }^{30}$

Afterward there is only one source can be found in the WTO documents on how is Indonesia opinion on the discussion on ecommerce, the Trade Policy Review in 2003. The Trade Policy Review Body asked what is the approach of Indonesia to the Work Programme on Electronic Commerce, in particular, on issues such as classification of electronic transmission and the definition of the mode of supply of services delivered by electronic means. ${ }^{31}$ This question was answered poorly, since the answer did not really describe on Indonesia's perspective on the matter.

Another question about recent implemented regulation which affecting e-commerce was answered that Indonesia is in the process of preparing a draft of Information and Electronic Transaction Law which will regulate e-commerce including privacy and personal data protection. ${ }^{32}$ Also the Consumer Protection Act is the Law of No. 8 of 1999 which gives protection to consumer. ${ }^{33}$

${ }^{29}$ Indonesia Statement by H.E. Mr. Jusuf Kalla Minister of Industry and Trade. Ministerial Conference Third Session Seattle, 30 November - 3 December 1999. WT/MIN(99)/ST/94.

${ }^{30} \mathrm{Id}$.

${ }^{31}$ Minutes of Meeting Trade Policy Review Indonesia with Chairperson: H.E. Mrs. Mary Whelan (Ireland). 11 September 2003. WT/TPR/M/117/Add.1.

${ }^{32} I d$.
${ }^{33} I d$. 


\section{B. The Effect of The Issue to Indonesia}

After observing the issue of e-commerce developed for more over a decade, then let us see what are the implications of the discussion upon Indonesia situation. Back in 1999, Indonesia did not have understanding on the issue, but still the technology has touched the life of Indonesia. The information technology has changed the way of Indonesia life; telecommunication becomes important in the society. The fact is shown by the increasing number of telephone mainlines was quite a frog leap, since it increased more $750 \%$ in 2004 compared to 1990 condition. $^{34}$ The same development also appeared in the number of cellular subscriber (from 0 to $138 / 1000$ people) and internet users (from 0 to $47 / 1000$ people). ${ }^{35}$

Compared to other developing countries those number is still low for a big country like Indonesia. As already mentioned before, that only certain level of society able to enjoy all of information and communication technology (ICT), middle to upper level economic. Even the enjoyment is limited in the certain economic level, but it will increase in the future because Indonesia has succeeded in preparing the development of the policy framework in the field of Information Technology. It is called the National Information Technology Framework that consists of five objectives to be achieved, namely: The achievement of E-Government for Good Governance by 2005, the achievement of E-Business to support SMEs by 2005, the achievement of IT basis for the society by 2010, the achievement of IT for education by 2010 , the achievement of E-Democracy by $2010 .^{36}$

Facing the rapid development of ICT and in pursuant to the framework, the government established several regulations concerning telecommunication, purposely to regulate the business player in ICT. Around 2001 the government started to implement electronic government in the administrative, although the plan went sporadic in provinces, the central keep urging the province government to implement it. It showed the will of the government to improve the administration by implementing e-government.

2008.

34 "Human Development Report 2006", <http://hdr.undp.org>, acessed 8 February

${ }^{35} \mathrm{Id}$.

${ }^{36}$ Trade Policy Review Indonesia. Report by the Government. 28 May 2003. WT/TPR/G/117. 
Moreover, the financial system absorbed the development of ICT quicker than any area, because in order to be in accordance to the international financial system it was redeemed necessary. Indonesia banking regulation is very complex just like other countries. The coverage is also as broad as international coverage, such as the procedure of e-banking system where Bank Indonesia has taken precaution steps in order to keep modern way of banking will have the same safety as the traditional way.

Since Indonesia mostly acted as a recipient or consumer in the ICT area, therefore Indonesia will be affected on the discussion on ecommerce in WTO. As recipient, Indonesia will be at advantage if favouring US in the discussion of classifying e-commerce. It is obvious if e-commerce classified as goods then GATT provisions will apply, which means with less cost this country can enjoy the benefit of the technology.

Of course, there is also disadvantage of it, becoming a recipient of technology all the time will not guarantee the competitiveness in developing ideas instead the dark side of this practice can resulted in the discouragement of novelty of ideas also research and development by locals. Unless of course government can come up with comprehensive plan on the domestic development of technology that will make Indonesia able to compete with developed countries either in area of e-commerce or other area with the support of e-commerce.

If Indonesia decides to favor EC argument, then Indonesia government must prepare for the future where online transaction can be levied on customs and duties. Of course it means additional costs to the transaction, but the autonomy to decide which service can enter the country is the government to decide. Therefore, government will be able to protect the society from liberalized competition which is possibly crippling the domestic products at present condition whereas not fully supported by legal, political and economic system.

In addition, the issue that was brought up by the $\mathrm{EC}$ in treating ecommerce as services is to protect the local content. Local content means the broadcasting ceilings for foreign content. ${ }^{37}$ This issue is the big question that the Indonesian government needs to answer, what is the local content in Indonesia, how important it is to be protected, what is the impact in decreasing the local content for Indonesian society. Those questions are need to be answered with deeply and thorough

${ }^{37}$ Sacha Wunsch-Vincent, The WTO, the Internet and Trade in Digital Products: EC-US Perspectives. Oxford and Portland, Oregon, 2006. 
research so there will be no mistake when the government gave their position in the debate of e-commerce in the WTO.

Both arguments have benefits and detriments, all depend on Indonesian government which to favour, it does not mean that Indonesia has to choose between the two, but it will be better if Indonesia already has a development plan on e-commerce. Therefore, no matter how the discussion in the WTO went, Indonesia will have a steady ground for its own development.

For sure, there is one thing that Indonesian government can take advantage, the joining in ITA. Because ITA was, establish in the purpose of encouraging nations to develop their ICT so there will be development in the ICT in order to create of fair competition. The encouragements were given in the form of reducing custom and duties on technology used for ICT. Indonesia must see ITA as the facility in building up the ICT in the country, despite the debate on the categorization of e-commerce, whether as good or services, Indonesia must take an immediate step redeem necessary to compete in the globalization of commerce, and maximizing the ICT development through available facility is one possible step right now.

\section{Conclusions}

The discussion on e-commerce in the WTO has not reached any decision yet. Opinion on how to regulate e-commerce was split into two major opposite opinions. US with the opinion e-commerce should be regulated as goods and $\mathrm{EC}$ with e-commerce should be regulated as services. These two opinions have not reach consensus, in fact the friction seemed became edgier in each Ministerial Meeting. Both opinions are understandable because the reasoning behind each opinion is logic, it is only a matter of deciding which will become the international regulation on e-commerce, and this is the hardest part.

The issue whether moratorium should be extended was also held up because the problem of classifying e-commerce has not been decided yet. But regarding the idea of maintaining the liberalized environment for ecommerce is something that every member states had already agreed to. In this situation where the practice has outpaced the regulation is the kind of situation where benefits is more for observer countries, such as Indonesia. Because this is the right time to absorb the usage of e-commerce as much as possible and use it to develop domestic technology. Nevertheless, the government of Indonesia should prepare for the possibilities of the two 
options come into being, and make a plan to overcome and survive without have to waste any useless effort. 


\section{References}

\section{Books}

Direktorat Perdagangan, Perindustrian, Investasi dan HKI, Departemen Luar Negeri. (Directorate of Trade, Industry, Investment and Intellectual Property. Foreign Ministry), Sekilas WTO.

World Trade Organization. Understanding The WTO, $3^{\text {rd }}$ Edition, 2005.

\section{Papers}

Electronic Commerce: "Briefing Note. Work Continues on Issues Needing Clarification", <http://www.wto.org/english/tratop_e/ecom_el ecom _briefnote_e.htm>, accessed 2 February 2008.

Human Development Report 2006, <http://hdr.undp.org>, accessed 2 February 2008.

Indonesia Statement by H.E. Mr. Jusuf Kalla Minister of Industry and Trade. Ministerial Conference Third Session Seattle, 30 November - 3 December 1999. WT/MIN(99)/ST/94.

Information Technology: "Introduction. Information Technology Agreement-Introduction", <http://www.wto.org/english/tratop_el inftec_e/ itaintro_e.htm>, accessed 2 February 2008.

Minutes of Meeting Trade Policy Review Indonesia with Chairperson: H.E. Mrs. Mary Whelan (Ireland). 11 September 2003. WT/TPR/M/117/Add.1.

Preparations for the 1999 Ministerial Conference. Compilation of Proposals Submitted in Phase 2 of the Preparatory Process. JOB(99)/4797/Rev.3.

Schuknecht, Ludger. "A Quantitative Assessment of Electronic Commerce, September 1999. Staff Working Paper ERAD-99-01”. <http://www.wto.org/english/res_e/reser_e/ae9901_e.htm>, accessed 2 February 2008.

Trade Policy Review Indonesia. Report by the Government. 28 May 2003. WT/TPR/G/117.

Work Programme on Electronic Commerce. "Submission by the United States.12 February 1999. WT/GC/16", <http://www.wto.org/ english/tratop_e/ecom_e/16_e.doc $>$, accessed 2 February 2008. 
Wunsch-Vincent, Sacha. "Outstanding WTO Issues and Deliverables with Respect to the Electronic Cross-border Trade of Digital Products. Thesis: Draft of Chapter 2, The WTO and the Liberalization of Crossborder Electronic Services: a translantic perspective. Washington DC, October 19, 2002", <http://www.cid.harvard.edu/cidtrade/ Papers/Wunsch_WTO.pdf.>, accessed 2 February 2008.

Wunsch-Vincent, Sacha. The WTO, the Internet and Trade in Digital Products: EC-US Perspectives. Oxford and Portland, Oregon, 2006.

\section{Interviews}

Hinderer, Adeline. European Commision, Directorate General for Trade. Trade in services, GATS, Investment.

Tuthill, Lee. World Trade Organization, Counsellor for Division du commerce des services. 